\title{
A Managerial Decision Making Capability Framework For Adopting Technology Innovation Within Construction SMEs : Analysis and Results
}

\author{
Mazura Mahdzir*, Sharifah Mazlina Syed Khuzzan
}

Kulliyyah of Architecture and Environmental Design, International Islamic University Malaysia, 53100 Kuala Lumpur, Malaysia

*Corresponding author: mazura.mahdzir@live.iium.edu.my

\begin{abstract}
The slow adoption of new technology within construction SMEs is influenced by the capability of managers in making decisions. Therefore, this paper aims to report the development of a conceptual framework related to managers' decision making capability in adopting technological innovation; specifically referring to Building Information Modelling (BIM). The primary data collection involves semi-structured interview, while the multiple-case (holistic) design was used for developing the managerial decision making capability framework. The development of the framework was analysed using comparative analysis (cross-case) of thirteen (13) top managers within the construction SMEs organisations. Comparisons were made between existing theories and new concepts raised by top managers. The findings revealed that regardless of various views obtained from top managers, the adoption of BIM software has been influenced by managerial non-behavioural and behavioural capability, that have been categorised into five (5) main themes.
\end{abstract}

Keywords: Decision making capability; top managers; construction, technology innovation adoption, conceptual framework

\begin{abstract}
Abstrak
Penggunaan teknologi baru yang perlahan dalam PKS pembinaan dipengaruhi oleh keupayaan pengurus dalam membuat keputusan. Justeru itu, kertas kerja ini bertujuan untuk melaporkan pembangunan rangka kerja konsep yang berkaitan dengan keupayaan pengurus dalam membuat keputusan untuk menerima pakai inovasi teknologi; khususnya Maklumat Building Modelling (BIM) . Pengumpulan data primer melibatkan temuduga separa berstruktur , manakala rekabentuk pelbagai- kes ( holistik ) telah digunakan untuk membangunkan rangka kerja keupayaan membuat keputusan.Pembangunan rangka kerja itu dibuat melalui analisis perbandingan di kalangan tiga belas (13) Pengurus bahagian dalam organisasi pembinaan (PKS). Metodologi kajian yang digunakan adalah 'cross- case' analisis. Perbandingan telah dibuat antara teori-teori yang sedia ada dan konsep baru yang dibangkitkan oleh pengurus atasan. Dapatan kajian menunjukkan bahawa tidak kira pelbagai pandangan yang diperolehi daripada pengurus atasan, penggunaan perisian BIM telah dipengaruhi oleh keupayaan bukan tingkah laku dan tingkah laku pengurusan, yang telah dikategorikan kepada lima ( 5 ) tema utama.
\end{abstract}

Kata kunci: Keupayaan membuat keputusan; pengurus atasan ; pembinaan, inovasi penggunaan teknologi, kerangka konseptual

(C) 2016 Penerbit UTM Press. All rights reserved

\subsection{INTRODUCTION}

The construction industry has faced various problems due to its fragmented practices among construction parties (e.g., Mohd Nawi et al., 2014) such as frequent delay on construction ( Razak et al., 2010; Abdullah, Azis \& Rahman, 2009), lack of skilled human resource, financial problems, marketing problems, low on-site productivity (Kaming et al., 1994), low quality, poor image, economic volatility and lack of data and information (e.g., Razak et al., 2010). This fragmentation practices might affect the overall performance of the construction industry (e.g., Zahrizan et al., 2013) and decelerates the economic growth (e.g., Abdullah, Azis \& Rahman, 2009).The emergence of technology innovation has become amongst the strategic decision made by managers to solve the fragmented practice (e.g, Zahrizan et al., 2013). Globally, technology innovation was employed by various countries and types of organisation either at a basic (e.g., internet-based tools as claimed by Mastura Jaafar et al., 2007, Zainon, Salleh \& Rahim, 2011) or advanced level such as Building Information Modelling (BIM). The evolution can be seen from PC, 2D CAD, 3D CAD, Industry Foundation Class, Virtual Reality, Web 2.0, Cloud Computing (e.g., Faizul A.Rahim, Nurshuhada Zainon \& Hafez Salleh, 2012) to the the latest technology such as BIM software (e.g., Faizul A.Rahim, Nurshuhada Zainon \& Hafez Salleh, 2012; Hua \& Chan, 2013;Wong \& Fan, 2013).

The utilisation of various application, software and programs (Barlish \& Sullivan, 2012) including BIM has been identified to assist managers in various activities such as (1) managing construction processes and communication effectively (e.g., Peansupap \& Walker, 2005, Zahrizan et al., 2013) and (2) managing information properly, which is normally contains large amount of documents (e.g., Zahrizan et al., 2013). Despite the benefits it's possessed, both western and non-western researchers have reported some problems in adopting such innovation. As for western countries (e.g., UK, USA, Australia, Taiwan, Korea, China, Hong Kong, Japan), the problems were more on BIM management once it has been adopted. For examples were technology related risks, slow transition/progressive change and process change issue and collaboration issue. This situation is definitely contradicts with non-western country which still at the 'nascent stage' of adoption, thus, contributes to the varying numbers of pre-adoption stage problem such as slow adoption or low rate of 
penetration of BIM. Malaysian construction industry (MCI) has been recognized as one of the countries that faced difficulties to adopt such innovation (e.g., Tan \& Ter, 2010), with emphasis given to SMEs organisation (CREAM , 2014).

\subsection{LITERATURE REVIEW}

Previous researchers agreed that 'people' should be the main issue in influencing the adoption of any new technology (e.g., Whyte, Bouchlaghem \& Thorpe, 2002; Russell \& Hoag, 2004; Peansupap \& Walker, 2005; Mastura Jaafar et al., 2007; Simmons, Armstrong \& Durkin, 2008; Mohr et al., 2009; Zhang \& Tao, 2012; Peltier, Zhao \& Schibrowsky, 2012; Nur Mardhiyah Aziz, Hafez Salleh \& Nur Khairul Faizah, 2012). From the perspective of SMEs researchers, the 'people-related issue' (e.g., Zhang \& Tao, 2012) was related to the weaknesses of top managers or so called managerial uncapability in order to recognise the value of technology (e.g., Tan \& Ter, 2010; García-Morales, Jimenez-Barrionuevo \& Gutierrez-Gutierrez, 2012) or due to their incompetent in the managerial aspects of decisionmaking (Carson \& Gilmore, 2000). The top managers or so called managers in adoption decision remains crucial since the decision to adopt new technology is quite complex (e.g., Nooraie, 2012; Mitropoulos \& Tatum, 1999; Whyte, Bouchlaghem \& Thorpe, 2002)

Innovation-based researchers have introduced various adoption theories to understand the multiple factors that influence managers' decision (e.g., Peltier, Zhao \& Schibrowsky, 2012; Ghobakhloo et al., 2012). These include models at individual level or organisational level such as Diffusion of Innnovation (DOI) theory, Theory of Reasoned Action (TRA), Technology Acceptance Model (TAM), Technology Acceptance Model (TAM) 2, Theory of Planned Behaviour (TPB), Unified Theory of Acceptance and Use of Technology (UTAUT), Upper Echelon Theory (UET) and Technology Organization Environment (TOE). However, the existing models on technology adoption have not provided sufficient insights on factors that could influence managerial adoption decision (e.g., Nor Hazana, Eta Wahab \& Alina, 2013). Some of the models have been proposed to correlate technology adoption with behavioral capability factors (e.g., age and experience) such as in IDT/DOI theory (e.g., Mumtaz Abdul Hameed, Counsell and Swift, 2012) and TAM theory. (e.g., Wu, 2011). Meanwhile some of the theories were developed to correlate the technology adoption with non-behavioral and behavioral capability factors, as incorporated in the TOE theory (e.g., Oliveira and Martins, 2011). Therefore, the theories available cannot give wider explanation related to the factors influencing managerial capability in adopting new technology (e.g., Wu, 2011; Garaca, 2011). Moreover, most of the theories were not suitable to be used during pre-adoption stage (e.g., UTAUT, TAM, TAM2, TAM3, TPB and TRA). It was undeniable that there are some of the theories (e.g., IDT/DOI, TOE, RBV and UET), have been developed to determine the adoption capability during pre-adoption stage. However, those theories were not comprehensive to cover the capabilities of the top managers itself.

Therefore, this study remains important to incorporate the multitude factors related to their decision making capabilities inter-personal capability within construction SMEs, specifically qs organisation. Guided by this framework, the top managers who came from SMEs organisations able to recognise their strength and weaknesses (based on the highest or lowest capability level) and then improve the capability that contains lowest points. By assisting them to determine their capability level, they can formulate a strategy if they intend to adopt BIM software. In simplest form, they will know which areas or aspects that require further improvement. Therefore, this framework prepares a useful tool for construction industry especially SMEs managers. This is consistent with various researchers that have reported the significance of each factor based on the theoretical and empirical data. The research data were collected from various (i) industries (e.g., tourism, services, business, construction, manufacturing, information technology, whole trade industry, management) and (ii) countries both from western (e.g., UK, US, Portugal, Italy, Australia) and a few from non-western (e.g., Malaysia, Hong Kong) (iii) fields of study (e.g., management, business). To achieve this, the following objectives need to be fulfil, which is to make a comparative analysis among thirteen (13) top managers of construction SMEs organisations (see research methodology for further details).

\subsection{THEORITICAL FRAMEWORK}

From the perspective of innovation adoption, researchers like Jackson, Farndale and Kakabadse (2003) and Lester (2014) share the meaning of capability with competencies (e.g., Vincent, 2008). Apart from competencies, capability has been associated with technical abilities (e.g., Beerel, 2009); ability to perform a particular task, activity or skill (e.g, Fitjar, Gjelsvik and Rodriguez-Pose, 2013), knowledge or aptitudes (e.g., Tamkin, Hillage and Willison, 2002), ability of firms to use their resources (e.g., Barney , 2001) or the way people act and what they know (Luoma, 2000). Meanwhile from the context of construction SMEs, the managerial decision making capability refers to the ability of top managers to make judgement in deciding whether to adopt new technology or not. The judgement to adopt has been influenced by two (2) categories of capability. The first category is behavioural capability factors , which include (i) managerial cognition (e.g., Hunter \& Cushenbery, 2011) (ii) managerial social capital (e.g., Kearney, Harrington \& Kelliher, 2014); (iii) managerial human capital (e.g., Zahrizan et al.,2013; Henderson \& Ruikar, 2010); and (iv) managerial behavior (e.g., Nor Hazana, Eta Wahab \& Alina, 2013). Second category is non-behavioural capability that includes (i) managerial demographic characteristics (e.g., Chuang, Nakatani \& Zhou, 2007; Colbert, Barrick \& Bradley, 2014)

\subsection{Managerial Cognitions}

Technically, Helfat and Peteraf (2014) define the term "cognition" into two (2) meanings: These include (i) mental activities (also termed "mental processes" or "mental operations") and (ii) mental structures (or representations). They further stated the concept of "managerial cognitive capability," which involves the capacity to perform the physical and mental activities (Helfat and Peteraf , 2014). Agree with the notion given by Helfat and Peteraf (2014), the cognitive capability is basically associated with the utilisation of both physical and mental ability in adoption decision. There are four (4) factors namely, (i) mindset or beliefs (ii) awareness and (iii) mission or vision and (iv) level of confidence, that shows positive correlation with adoption decision (see Figure 1). Through seminars and workshop,all positive capability factors can be injected among managers, which in turn influences them to adopt IT in speedy manner (e.g., Manral, 2011; Spencer, Buhalis and Moital, 2012). First is related to 'mind set' factor that always being synonymous with a set of attitude held by someone or based on previous experience (e.g., Nur Mardhiyah Aziz, Hafez Salleh and Nur Khairul Faizah Mustafa, 2012). Second is related to the awareness on the important of technology adoption. This is supported by Ongori and Migiro (2010) and Zahrizan, et al., (2013), which have revealed the positive correlation between managerial decisions with level of awareness regarding technological 
benefits. Third is related to managerial mission or vision. Based on the empirical studies conducted by Nor Hazana, Eta Wahab and Alina (2013), they have managed to show one of the significant factors that could have influence in adopting new technology namely having clear mission for organisational direction (e.g., Egbu, 2004). Fourth is concern with confidence level, which might affect their adoption decision. Brewer and Runeson (2009) and Peansupap and Walker (2006) are the examples of researchers that have shown the positive correlation between these two variables.

\subsection{Managerial Social Capital}

In essence, managerial social capital refers to managers' ability to access resources (e.g., including identifying technology adoption) through relationships and connections (as cited by Kor and Mesko, 2013 in Adler and Kwon, 2002). Generally, it can be divided into two (2) forms namely external and internal relationship (see Figure 1). First is external relationship. It refers to inter-organizational networks or relationship that was build up in the forms of (i) 'business networks' (through their normal client and supply chain interaction) or (ii) 'institutional networks' (such as educational institutions, government bodies, research institutions and professional associations) (e.g., Sexton , Barrett And and Aouad, 2006).Second is internal relationship. It refers to intra-organizational networks or relationship which is developed between employees (e.g., Eckenhofer, 2011). Building a good relationship externally or internally might give many benefits towards managers. For instance, Hai, Jing and Jintong (2013) indicate that this factor is needed to widen the networking opportunities. The previous findings were parallel with researcher such as Azadegan and Teich (2010), Hai, Jing and Jintong (2013) and Kearney, Harrington and Kelliher (2014), which found the significance of developing strong relationships externally (e.g., other organisations) or internally (e.g., employees). In doing so, all information related to decision making (e.g., advice on the selection to adopt better technology) could be obtained, which indirectly assist them to speed up their decision to adopt innovation (e.g., Gelatkanycz and Hambrick, 1997).

\subsection{Managerial Human Capital}

Managerial human capital refers to the knowledge of specialized resource strategies and managerial skill set (e.g., Kor and Mesko, 2013). However, within this context, the managerial human capital is concern with managerial development of skills and knowledge. The related factors have been broadly grouped into several sub-categories; namely (i) knowledge, (ii) training, (iii) IT skill, (iv) personal skill, (v) language skill, (vi) problem solving skill, (vii) entrepreneurial skill, and (viii) technical skills, (x) managerial skill (see Figure 1). First is knowledge. Managers should be equipped with knowledge and information technology to foster better technological adoption, otherwise the adoption remains difficult (e.g.,Thurairajah and Goucher, 2013). The findings were consistent with Peansupap and Walker (2005) and Tan and Ter (2010). They mentioned that the slow action to adopt new technology was due to minimum understanding or inability of managers to recognise IT as a technological innovation. Second is training. It has become another factor that shows positive influence towards technological adoption. This was proven when previous researchers argued that the lack of training and the domain experts in construction organisation (e.g., Hassan Issa and Abu Hassan, 2011; Yang et al., 2007) have influenced the slow action to adopt new technology. Third is IT skill, which has affected the use of innovation. Based on the study of a small sample of Australian organizations, this skill has been identified as one of the important factor that affect the use of new technologies in the construction organization (Peansupap and Walker, 2005). Fourth is personnel skill.. Azadegan and Teich (2010) claimed that top managers will be more ready to adopt new technology if they equip themselves with personal skill. Fifth is language skill. Barba-Sanchez, Martínez-Ruiz, Jimenez-Zarco (2007) have stated the importance of language skills in influencing the managerial decision. Sixth is problem solving skill. From a critical literature review drawn from the hotel micro firm, Kearney, Harrington and Kelliher (2014) found that managers need to acquire the problem solving skill (e.g, to solve operational problems through increased ability to shape resources) towards better innovation adoption. Seventh, the previous researchers have identified the need of entrepreneurial skill of SMEs (e.g.,Nam and Tatum , 1997). Basically, this refers to the skill of top managers to detect and identify entrepreneurial opportunities (e.g., Hai , Jing and Jintong 2013) . Zhang and Tao (2012) have stressed further that the importance of enhancing this skill among SMEs by strengthening their self-study and self-training, develop a positive attitude, and work in a down-to-earth manner. Eight is technical skill. Generally, Tatum (1987) defined that strong technical skills is a key capability for innovation. Technical capability is necessary to analyze the design requirements of many current projects. Ninth is managerial skill that can be associated with top managers' ability to effectively organize, allocate, and configure various firm resources (e.g., Hai, Jing and Jintong, 2013). It is needed more than technical skills (Pratali , 2003).

\subsection{Managerial Behaviour}

As for managers, the way they react towards technology remains a key to drive towards better adoption (e.g., Kearney, Harrington and Kelliher, 2014). Through theoretical and empirical findings, the managerial reaction can be in the forms of (i) motivation or support, (ii) commitment, (iii) attitudes, (iv) strategy and (v) leadership behaviour, which should be possessed among them (see Figure 1). First is motivation or support which is essential factor to contribute positive technological adoption (e.g., Manral, 2011).This concept, has been practically applied by IT researchers as they believed the motivation (e.g., extrinsic and intrinsic) has influenced the electronic data interchange (EDI) adoption decision among fifty (50) Bruneian SMEs. (e.g., Seyal, Mohd Noah and Awg Yussof, 2007). Second is commitment. The term refers to the state of being involved in an obligation (Oxford Dictionary). Commitment is totally needed by managers as this factor managed to influence them to adopt new technology (e.g., Shiels, McIvor and O'Reilly, 2003) and contributes to the successful adoption of technology innovation (e.g., Nguyen, Newby and Macaulay, 2013).Third is attitudes. In essence, the attituditional factor can be defined as a way of thinking or behaving of people (Oxford dictionary).The term is synonymous with their response towards technology and process (e.g., Ren and Kumaraswamy, 2013). Previous researchers have proven that most of the studies showed that managerial attitudes have direct influence towards IT adoption. (e.g.,Mazuki Jusoh, Mohd. Rizal Abdul Razak and Maimun Simun, 2004). Fourth is strategy. Stewart and Fenn (2006) pointed out the importance of creating a strategy to improve competitiveness among other organisations. These include (i) to encourage active participation, teamwork and familiarise with IT (e.g., Breuer and Fischer, 1994) (ii) to convince people about the potential of technologies like BIM adoption, developing education program and changing management style (e.g., Zahrizan, et al., 2013). Fifth is leadership behaviour, which has become another factor that might influence top 
managers in deciding whether to adopt innovation or not (e.g., Ozorhon, 2013; Jong and Hartog, 2003; Nam and Tatum, 1997; Meng-Han, Mony and Shang-Hsien, 2014). Jong and Hartog (2003) states that the definition of leadership varies; either refers to the leader abilities, personality traits, influence relationships, individual versus group orientation, and appeal to self- versus collective interests. Within this research context, it concerns with the leadership styles (e.g., Nor Hazana Abdullah, Eta Wahab and Alina Shamsuddin, 2013;Aslan, Diken and Sendogdu, 2011; Isabelle et al., 2014; Colbert, Barrick and Bradley, 2014; charismatic leadership Isabelle et al., 2014 and Egbu, 2004).

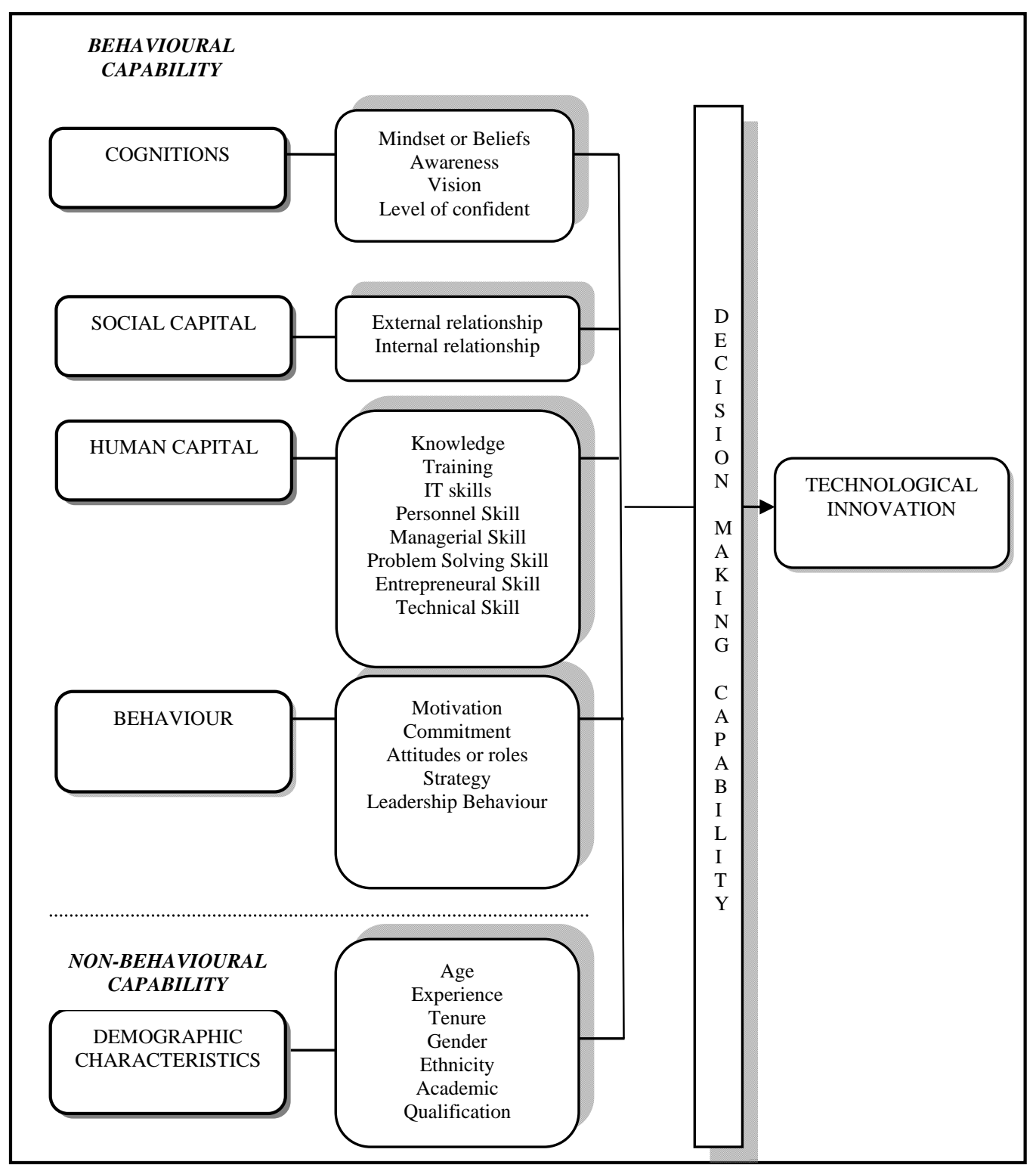

Figure 1 Initial conceptual framework related to managerial decision making capability

\subsection{Managerial Demographic Characteristics}

There are several sub-categories involved namely (i) age; (ii) experience; (iii) academic qualification (iv) gender; and (vi) tenure (see Figure 1). First, is age. There are many empirical findings indicate positive relationship between age and decision to adopt technological innovation. The example given by Perez, Sanchez and Carnicer (2003), which have shown the potential of younger managers in influencing the adoption of tele-working rather than older managers. Second, is experience. Many researchers claim the significance of managers to gain as much as experience, so that they confident to adopt technology innovation quickly. Among empirical studies that stressed the importance of experience was Zahrizan et al. (2013). However, the previous findings were not consistent with Khong et al., (2010) who revealed that experience was not important in adopting IT. Based on the questionnaire-based survey that was conducted among 406 managers or owners of SMEs in Malaysia, they found that SMEs would adopt internet-based ICT regardless of years of business startup and internet experience. Third, is academic qualification. Many empirical studies indicate the positive influence of academic qualification in assisting managers to adopt technology innovation in SMEs organisation such as Ta-Tao, Zhou and Nakatani, 2007; TaTao, Nakatani and Zhou, 2009; Spencer, Buhalis and Moital, 2012) . Fourth, is gender. Previous studies have shown positive relationship 
between gender and IT adoption decision It was proven when males has been apparently more inclined to adopt technology compare to their female counterparts (Awa et al., 2011). Fifth is tenure. Previous studies have shown that tenure gave positive influence towards assisting them to adopt technology adoption (Colbert, Barrick and Bradley, 2014). A questionnaire survey involving one hundred and fifty seven (157) responses from executive and human resources managers, indicates that younger managers with long tenure tends to adopt tele-working compared to older managers with minimum tenure (Perez ,Sanchez and Carnicer, 2003). Sixth, is ethnicity (e.g., BarbaSanchez, Martinez-Ruiz, and Jimenez-Zarco, , 2007).

\subsection{METHODOLOGY}

\subsection{Research Design}

For this research, multiple-case (holistic) designs remains the most appropriate design to be used due to the study contains more than a single case. Among the advantages of having more than one (1) case are (i) it provides rich information compared to single unit of case (e.g., Yin, 2009) (ii) depth investigation and interpretation of information could be specifically explored (e.g., Morgan, 2008) (iii) due to follow a "replication" logic or test the conclusions (e.g.,Yin, 2009). The multiple cases also are more suitable with holistic design as (i) no logical sub-units can be identified as the focus is on managerial views only and (ii) when the relevant theory underlying the case study is itself of a holistic nature (e.g., Yin, 2009).

\subsection{Selection of the Respondents}

There were thirteen (13) respondents involved for this study (as stipulated in Table 2). They are top managers of organisational A to M namely the Board of Directors, the Associate Partner and the Senior Manager. Using purposive sampling, they are registered quantity surveyors that have been chosen from BQSM databases. Some of them have been chosen within Klang Valley area and Perak. The selection is based on several reasons: (i) the accessibility (location factor and time constraints) and (ii) confidentiality basis (openness to shares their points of view) (iii) they are the one who involve in decision making to adopt BIM software (iv) they have working experience for at least more than four (4) years in construction organisation and at least more than eight (8) years in construction industry (v) they are the person that can be rely on and learned most as stressed by Meriam (2001). This is also consistent with Creswell (2008) which highlighted the involvement of experience and knowledgeable managers via 'information rich' method remains crucial to obtain better insights with regards to the factors influencing the adoption of new technology so called software. There are seven (7) types of software namely Building Information Modelling (BIM), Computer Aided Design/Drafting (CAD), Masterbill, Global Estimating System (Buildsoft), RIPAC Estimating System, Quality Service Management System (QSM) and CATO Software (e.g.,Nuradillin Hasnul Hafidzan, 2015). Out of seven (7), the study intends to focus on BIM software as it has become one of the form of technology (e.g., software) that have been used to integrate parties in construction lately. The BIM software can be in various forms, such as Cost $\mathrm{x}$, Glodon, Revit and etc. The adoption of BIM software contains many benefits such as improving project's accuracy (e.g., Zhou et al., 2012) and promotes integration (e.g.,Rezgui, Beach \& Rana, 2013; Sackey, Tuuli \& Dainty, 2013). Within the context of a Quantity Surveying, the estimation can be automated or accurate interpretation of designs and numerical representation of component quantities can be achieved with BIM (e.g., Gayathri, Himal \& Ranadewa, 2013).

\subsection{Data Collection}

The preferable technique used in collecting the primary data is semi-structured interview. This selection is parallel with Esterby-Smith, Thorpe and Lowe (2002), which claimed this technique as the most fundamental in qualitative methods. Besides that, an interview session provides more insights in explaining the causal relationships and inferences compared to questionnaire survey which is more rigids and contains limited structure. Guided by case study protocol (e.g., contains several open and close-ended questions), the exploration of manager's view pertaining to their capability in influencing the adoption of new technology was conducted. This session comprises of two (2) parts which was held in the forms of face-to-face interview. Both parts involves semi-structured interview among top managers that have an authority to decide in organisation. The open-ended questions are drafted concisely based on the systematic literature review. The second part involves similar method, which is semi structured interview but the questions have derived from the combination of open and closed ended. The questions have been guided with initial conceptual framework which has been proposed as well as concise literature from various researchers. This session is conducted to obtain better insights of managerial views pertaining to their stand in relation to the significance of each factor and other factors proposed previously. This session is recorded via tape recorder and aided with note taking to ensure the accuracy of data and to make the interviewer alert with the information given by interviewee. To be more effective, the case study protocol has been sent via e-mail before conducting the session. The purpose is to give an ample time and ease the respondents in answering the questions in advance.

\subsection{Data Analysis}

Generally, the qualitative content analysis is chosen for analysing the relevant data in the case study method (Bhattacherjee, 2012). This is due to the fact that a lot of information and data can be collected and organised. Besides that, the qualitative analysis contains economical benefit. The data coded can be evaluated, and this offers better time and cost saving. Also, it permits study processes to be reviewed with long periods of time, which is parallel to this research study that have made an analysis from 1980s to the present date (e.g., Babbie, 2010). According to Miles and Huberman (1994), they state that the qualitative analysis can be divided into three (3) stages; (1) data reduction, (2) data display (3) conclusion. First is data reduction. The data obtained from interview and documents should be organised and reduced into the simplest forms and systematic manner such as coding, writing summaries and discarding irrelevant data. Second, is data display. The management of data is displayed in the forms of tables, charts, networks and other graphical formats. Third is drawing a conclusion, whereby the initial conclusion is made before continuing with validation process. For this study, it starts with categorising the factors 
influencing manager's decision making capability systematically into several main themes via pre-defined matrix to get the overall pattern of research topic. Fellows and Liu (2008) explained further that the data will be coded according to the group that have the similar data to form a matrix cell. The data which has been categorised should maintain its uniqueness and holistic. Then, the analysis continues with analysing the cases comparatively. Table 1 depicts the summary of the analysis technique and research objectives used for this research study.

Table 1 The analysis technique and the main objective used for developing the framework

\begin{tabular}{|c|l|l|}
\hline No & Research Objectives & Analysis Technique \\
\hline 1 & $\begin{array}{l}\text { To make a comparative analysis among thirteen (13) top } \\
\text { managers of construction SMEs organizations }\end{array}$ & Cross-case analysis \\
\hline
\end{tabular}

\subsection{RESULTS AND DISCUSSION}

\subsection{Introduction}

This study prefers to use qualitative approaches as it offers an explorative way in searching the information. This approach seeks to find out the reasons behind such event. (e.g., Fellows and Liu, 2008). Thus, within this context, the study has identified 'what' are the causes (e.g., capability factors) that might influence them to decide. This is due to the reasons that the managerial factors differ based on different countries, size of organisation and types of organisation. To achieve this, a semi-structured interview among thirteen (13) top managers were conducted, who have represents the case study organisations from A to M. The analysis begins by introducing the respondent's background from the construction SMEs before comparing the analysis findings from several respondents.

\subsection{Research Background}

The details of the respondents were recorded and summarized as below:

Table 2 Background of the respondents (s) for a case study organisation(s)

\begin{tabular}{|c|c|c|c|}
\hline $\begin{array}{c}\text { Case study } \\
\text { Organisations }\end{array}$ & Position of the respondent(s) & $\begin{array}{c}\text { Year of experience with } \\
\text { current organization }\end{array}$ & $\begin{array}{c}\text { Years of experience in } \\
\text { construction industry }\end{array}$ \\
\hline A & Senior Manager & 19 years & 19 years \\
\hline B & Board of Director & 4 years & 19 years \\
\hline C & Board of Director & 4 years & 10 years \\
\hline D & Senior Manager & 9 years & 13 years \\
\hline E & Senior Manager & 10 years & 10 years \\
\hline F & Board of Director cum Managing and Senior Manager & $>4$ years & 30 years \\
\hline G & Board of Director & 13 years & $>20$ years \\
\hline H & Board of Director & 5 years & 23 years \\
\hline I & Board of Director & 13 years & 30 years \\
\hline J & Board of Director & 5 years & 22 years \\
\hline K & Associate Partner cum Senior Manager & 10 years \\
\hline L & Associate Partner/Managing Director & 10 years & 32 years \\
\hline M & Senior Manager & 13 years & 16 years \\
\hline
\end{tabular}

\subsection{Cross-case analysis for managerial decision making capability}

There are five (5) main-themes have been identified by previous researchers which include cognition, social capital, human capital, behaviour and demographic characteristics. Out of five (5) main themes, about four (4) main themes have been categorised into one heading so called behavioural capability and the another main theme (i.e, demographic characteristics) has been categorised under the heading of non-behavioural capability. The details discussion on the several themes related to managers can be refers as follow:

\subsubsection{Managerial Cognitions}

The analyses of behavioural capability factors are discussed and sub-divided into four (4) sub-themes which are; (i) mindset or beliefs (C1), (ii) awareness (C2), (iii) vision (C3), and (iv) level of confident (C4).

First is mindset or beliefs. There are evidences that mindset such as 'strategic thinking' (Kearney, Harrington \& Kelliher, 2014), 'inspiration or intellectual stimulation' (e.g., Isabelle, Anita \& Fellows, 2014; Spencer, Buhalis \& Moital, 2012; Jong \& Hartog, 2003) and 'idea suggestion' (Hunter \& Cushenbery, 2011) will motivate them to adopt BIM in fast manner. The similarities of finding can be found between previous literatures and current study (e.g., A to M). Overall, they agree that mind setting or beliefs about BIM benefits will influence them to expedite the adoption of BIM software. For instance, the top managers from organisational B,C,F and I are extremely believed with the BIM potential to facilitate the organisational operation. For instance organisational A reveals that the adoption Specialized Quantity Surveying software packages such as Glodon and Binalink will facilitate them in expediting the measurement works. The positive mind set is also has been shared by managers from case study organisation $\mathrm{C}$. From his perspective, only qs can arrange the quantities elementally compared to engineers and architect. It has been agreed by organisational F and I, as they consider BIM as an exclusive and beneficial 'tools'. Therefore this factor will be listed in the conceptual framework.

$\mathrm{C} 1$ : Mindset or beliefs is influence manager's decision to adopt BIM software 
Second is awareness. Previous researchers such as Ongori \& Migiro (2010) and Zahrizan et al., (2013), have revealed the link between awareness and BIM adoption. This is consistent with the managers from organisational A, B, C, D, F, H, L and K, who aware about BIM from their clients. This will indirectly influenced them to study the benefit of BIM software. It was basically designed to assist designers including qs to reduce the time related to preparation of bq. With a clear visualisation, all measurement quantity can be automated quickly. On top of that, the manager from organisational $\mathrm{F}$ believe the idea of using 3-D system was not only to save time, but also provides better networking and enable data between construction parties to be shared widely. There are also other top manager (e.g.,I) who realizes the disadvantages of BIM characteristics (e.g., standard protocol and formatting). Such software was seen not important, in which will give difficulties in certain condition such as in management process and etc (e.g., E,J and M). These results suggest that awareness among managers remains an important factor in influencing them in decision making process. Therefore, this factor will be listed in the conceptual framework.

\section{$\mathrm{C} 2$ : Awareness has positively influence manager's decision to adopt BIM software}

Third is managerial vision. It can be seen clearly in the studies of Hunter \& Cushenbery (2011), Egbu (2004) and Nor Hazana, Eta Wahab and Alina (2013). The result of the studies showed the need to express a clear vision before adopting any new technology. The previous findings also accord with the current case study organisations (e.g., A to M). This is apparent when managers from organisational A, E, G,H, J, K, M are quite comfortable with existing software. From their perspectives, the adoption of BIM software was not important at the moment. They focus more on providing the best services towards their clients. Meanwhile, the managers from case study B, C, F, I and $\mathrm{L}$, are quite interested to adopt BIM in future years by planning an appropriate strategy such as (i) to adopt more software packages after adopting one (1) license (e.g., C) (ii) to adopt BIM software at a reasonable price (e.g., E). Thus, this factor will be listed in the conceptual framework.

\section{C3 : Vision has positively influence manager's decision to adopt BIM software}

Fourth is level of confidence. The previous researchers such as Brewer and Runeson (2009) and Peansupap and Walker (2005) have shown positive correlation between BIM adoption and high level of confidence by top managers. Earlier studies are consistent with the case study organisations from A to M. From the case study findings, manager from organisational B shows high confidence level about BIM. For him, BIM remains relevant for construction SMEs if government follows the systematic tendering system as practised by construction in Singapore. This is parallel with the main intention to let everyone knows about BIM in Malaysia. The top managers from organisational C and D also confident with the potential of BIM software in measuring structural works for low rise projects or complex design (e.g.,hospitals). They believe that they will adopt more licenses if the issues related to BIM software can be solved, which indirectly increase the confidence level of organisational A, E,F,G,H,I, J, K, L and M towards BIM adoption. This factor remains important and will be listed in the conceptual framework.

\section{C4 : Level of confident has positively influence manager's decision to adopt BIM software}

\subsubsection{Managerial Social Capital}

The analyses of behavioural capability factors are discussed and sub-divided into two (2) sub-themes which are; i) external relationship (SC1), and, ii) internal relationship (SC2).

Firstly is external relationship. Previous literatures claimed that it is important to build close relationship in order to solve the minimum interactions between the various parties in construction (e.g., Sexton, Barrett \& Aouad, 2006). The case study findings from organisations A, B, C, F, G, I, J, K, L and M show similar results with previous studies. For instance they admit the significance of building external relationships (e.g., via meeting, seminars or online) with other organisations. Through this relationship, it enables them to share information about BIM potential and its challenges. The information related to advantages and disadvantages of BIM will be considered before deciding to adopt. If the BIM characteristics match with their organisational capability, the tendency to adopt will be high. This notion is shared by organisational $\mathrm{B}, \mathrm{C}$ and $\mathrm{D}$, which reveal their capability in terms of cost and professional expertise. This will indirectly leads to the adoption of BIM software expeditiously. This notion is contradicts with organisations $\mathrm{H}$ and E, which basically stress the external relationships has not playing an important factor in influencing their decision. From their point of view, the client's requirement is more important. If no complaints received from their respective client, they will not consider adopting BIM software even though other organisations recognise the benefit of BIM software. Meanwhile there are no views raised by managers from organisational C pertaining to the relationship of external relationship in influencing their adoption decision. Based on the majority views that have supported the significance of this factor, it is relevant to maintain it in the conceptual framework.

\section{$\mathrm{SC1}$ : External relationship has positively influence manager's decision to adopt BIM software}

Secondly is internal relationship; it was evident that previous studies (e.g., Kearney, Harrington \& Kelliher, 2014; Hai, Jing \& Jintong, 2013) reveal the importance of internal relationship in influencing top manager's decision making. The studies have revealed that an appropriate interaction or so called, inter-organizational networks within organisation will allow better knowledge sharing and indirectly support the adoption of new technology. The emerging case studies (e.g., A, B, D, F, G, J, K, L and M) are consistent with the previous literatures. This is agreed by the managers from organisational A, B, D, F, G, J, K, L and M, which reveal several ways that might help them to interact between each others. For instance (i) through the creation of new layout or congenial environment (e.g., organisational A, M), (ii) building an intra-organisational networking that can be made in formal or informal way (e.g., organisational B, J, K, L). However, this factor is not important for organisational E. Despite they have already practise the inter-organisational networking, but it does not works (influence the adoption of BIM). The similar notion is shared by manager from organisational $\mathrm{H}$ which states that managerial relationship with bottom level has not become a direct factor to adopt BIM software. Meanwhile there are no views raised by managers 
from organisational $\mathrm{C}$ and I pertaining to this factor. Based on the majority perceptions given by managers, these results still suggest the significance of internal relationship in the conceptual framework.

SC2: Internal relationship has positively influence manager's decision to adopt BIM software.

\subsubsection{Managerial Human Capital}

The analyses of behavioural capability factors have been categorized and discussed into eight (8) sub- themes, which are: knowledge (HC1), training (HC2), IT skill (HC3), personnel skill (HC4), managerial skill (HC5), problem solving skill (HC6), entrepreneurial skill (HC7) and technical skill (HC8).

First is knowledge. Many studies from previous literatures (e.g., Nor Hazana, Eta Wahab \& Alina, 2013; Peltier, Zhao \& Schibrowsky, 2012; Peansupap \& Walker, 2006; Nguyen, Newby \& Macaulay, 2013), showed the positive relationship between knowledge and BIM adoption. It is needed to expedite the decision making among top managers. The researchers believe that top managers must be knowledgeable so that they can understand the processes and activities (Carson \& Gilmore, 2000). The emerging case (e.g., A to M) has supported the previous literatures. For instance, they (e.g., organisational A, B, C, D, E, F, H, I, J) admit that knowledge regarding technology is able to help them in many ways which are (i) to run the project effectively and smoothly (ii) to get some ideas about any new things (iii) to analyse early variation works (iv) to differentiate the advantages and disadvantages of BIM (v) to gain thorough understanding before made a final decision whether BIM really benefited their organisations. Therefore, this factor will be listed in the conceptual framework.

$\mathrm{HC1}$ : Knowledge has positively influence manager's decision to adopt BIM software

Second is training. The training especially hands-on training can speed up the adoption of BIM as have been described by earlier studies (e.g; Hassan Issa \& Abu Hassan, 2011). Without training, the adoption of new technology remains at low level (Hassan Issa \& Abu Hassan, 2011; Yang et al.,2007). There are similarities between the training expressed by current findings (e.g., A to L) and those described by earlier studies. For instance, they have showed their high priority to attend training to familiarise with the system and to control their staffs (e.g., B and E). Besides that, there are some of them that indicate their readiness to attend hands-on training about BIM software. From their point of view, if they able to attend two (2) or three (3) times training at least they can understand the basic of the software. It is crucial to generate idea regarding BIM concept because the adoption of BIM was not a simple thing (e.g.,I and $\mathrm{K})$.Meanwhile, for some managers, they have not interested to attend hands-on training, which leads to the low priority of adopting BIM software (e.g.,C,D,F,G,H,J and L). For these reasons, this factor will be listed in the conceptual framework.

HC2: Training has positively influence manager's decision to adopt BIM software

Third is IT skill. Previous studies have proved that decision to adopt BIM has been influenced by their skill in IT (e.g., Peansupap \& Walker, 2005; Junaidah Hashim, 2007; Zahrizan et al., 2013). It is needed to avoid slow and late adoption of new technology. This current finding (e.g., B,D, E,G,H,I,J,K and M) corroborates the ideas of earlier researchers, who suggested the development of such skills in adopting BIM software. Overall, they express the need to possess IT skill to manage the organisational performance. The adoption of BIM could be done quickly if the clients consider the following condition : (i) reasonable cost of installation is reasonable and attending sufficient training (e.g., C), (ii) longer period of time has been allocated to learn IT skill (e.g., E) and (iii) the learning initiatives was initiated by client (e.g., F). Meanwhile another groups (e.g., A,C, and L) have not shared their views pertaining to this skill in facilitating the adoption of BIM. Based on the majority views collected among top managers, these results suggest that IT skill is still important to be listed in the conceptual framework.

HC3 : IT skill has positively influence manager's decision to adopt BIM software

Fourth is a personnel skill. The previous literatures showed the significance of personnel skills in influencing managerial adoption decision (Azadegan \& Teich, 2010). The current study (e.g., A, B, F,G and L) is in agreement with Azadegan and Teich (2010) findings which claimed that top managers with personnel skills, will be more ready to adopt new technology. They further believe the importance of such skill in terms of (i) to support the staffs performance by injecting positive values among staffs (e.g., A) or reward the senior staffs (e.g., F) (ii) to develop critical thinking among staffs (e.g., B) (iii) to manage the projects and staffs in better way (e.g., G). The relationship between top level and bottom will indirectly assist managers to determine the level of attitudational behaviour possessed by their staff (e.g., openness towards changes). Meanwhile, for some of them, (e.g.,C, D, E, H, I, J, K and M) this factor have not influenced their adoption decision. Based on the majority views identified from top managers, these results suggest that personnel skills remain an important capability factor to influence managerial decision making process. This factor will be listed in the conceptual framework.

\section{HC4 : Personnel skill has positively influence manager's decision to adopt BIM software}

Fifth is a managerial skill. A study made by Hai, Jing and Jintong (2013) showed that with strong managerial skills, managers could configure managerial ties (e.g., relationship) and allocate and configure resources effectively. The ability to manage the organisational operations will indirectly make them aware about their organisational capability to adopt BIM. The current findings (e.g., A, B, G, K) are consistent with the idea raised by previous studies. The managers of case study organisations A, G and K admit the significance of managerial skill in determining the readiness of their organisations towards changes, manage the projects and supervise the staffs' work effectively. Other top manager (e.g., B) also admits that this factor remains important to provide an independent learning for their staffs in dealing with new software. As a result, the staffs' competency can be improved simultaneously. Meanwhile, for organisational C, D, E, F, 
H, I, J, L and M they have not discussed the significance of this factor during the interview session. Since there are some of them (minority views) believe with this factor in influencing their decision to adopt BIM software, this factor will be listed in the conceptual framework..

HC5: Managerial skill has positively influence manager's decision to adopt BIM software

Sixth is problem solving skill. Previous researchers (e.g., Kearney, Harrington \& Kelliher, 2014) have also found the significance of this skill among top managers. The ability to solve operational problems will build their confidence level in handling any issues (including BIM adoption), which indirectly influencing their decision to adopt BIM. Unfortunately, majority of them have not shared their views pertaining to this skill in facilitating the adoption of BIM. Similarly for the minority view received from managers A and G, despite they share that this factor enables them to be more proactive to settle any issues, this factor does not really assist them to adopt or reject the technological innovation. Therefore, this factor will not be listed in the conceptual framework.

HC6: Problem solving skill has not influence manager's decision to adopt BIM software

Seventh is entrepreneurial skill. The significance of entrepreneurial skills in influencing the managerial decision has been highlighted by earlier studies (Hai, Jing \& Jintong, 2013; Zhang \& Tao, 2012; Nam \& Tatum, 1997). The previous literatures managed to indicate positive correlation between this skill and BIM adoption (Zhang \& Tao, 2012; Nam \& Tatum, 1997). However, it is not consistent with the current findings. The top managers from A to $\mathrm{M}$ revealed that this skill has not playing an importance factor towards BIM adoption. They do not share any view pertaining to this skill. One of the top managers (e.g., G) also admits that it does not help them to update any news related to construction projects including the benefits and challenges of BIM software. For this reason, this factor will not be listed in the conceptual framework.

\section{HC7: Entrepreneurial skill has not influence manager's decision to adopt BIM software}

Eight is technical skill. The researchers such as Tatum (1987) and Nam \& Tatum (1997) have found that a strong technical skill is important to help them analyze the design requirements, which leads the quick adoption of BIM software. The current findings (e.g., A to M) support the idea obtained from the previous studies. Manager from case study organisations B and D explain the importance of equipping such skill for better supervision in calculation works. Meanwhile top managers from organisational $\mathrm{C}$ states that this skill enables every staff recorded all their works (e.g., measurement) properly. This notion also has been agreed by managers from organisational E, F, G, I and L. The skill is needed for several reasons namely (i) to detect any mistakes related to measurement of architectural and structural works (i) to increase the understanding about 3-D drawings (ii) to compete with other consulting organisations (iii) to encourage themselves to learn a new things (iv) to encourage themselves to supervise qs works efficiently. Similar notions have been expressed by managers from organisational A, J and M. From their perspective, the high technical skill possessed among managers would assist them in managing the BIM unit which has been established within their organisation. Failure to have this skill will cause them difficult to detect any measurement errors or hidden dimension that could not be seen clearly in drawings. While majority of them believe with the significance of this skill, some of them (e.g., $\mathrm{K}$ and $\mathrm{H}$ ), do not share any views related to the technical skill in influencing managers to adopt BIM expeditiously. It can be concluded that this factor will still be listed in the conceptual framework after receiving majority views from the top managers.

HC8: Technical skill has positively influence manager's decision to adopt BIM software

\subsubsection{Managerial Behaviour}

The analyses of behavioural capability factors are discussed into five sub- themes (5) which are motivation or support (B1), commitment (B2), attitudes (B3), strategy (B4) and leadership behaviour (B5).

First is motivation or support. Based on the previous literature (e.g., Manral, 2011; Afzaal, Mohd Noah \& Hj Awg Yussof, 2007; Fink, 1998), the motivation or support (e.g., extrinsic and intrinsic motivation) will influence the managerial behaviour. The result has been found by researchers in IT which revealed the need of motivation in adopting electronic data interchange (EDI) among Bruneian SMEs (Afzaal, Mohd Noah \& Hj Awg Yussof, 2007).It is consistent with the case study organisations A to M. For some managers (e.g., B, C and D), this factor is highly needed to deal with BIM software but requires several considerations (i) to provide a maintanence centre and expertise to in-charge for technical parts (ii) to provide better guideline pertaining to BIM inter-operability issue, which leads to the adoption of software licenses. This is agreed by top managers from $\mathrm{J}$ and $\mathrm{K}$, which admit that the adoption of BIM software can be expedited with following condition (i) they can get at least one (1) or two (2) government projects a year to obtain reasonable fees (ii) they have an opportunity to explore in detail this software. Meanwhile for other organisations, they do not have any motivation to adopt new changes (e.g, A,E,F,G,H,I,L and M), due to (i) the less enforcement by their clients, (ii) BIM operationability (e.g., complexity) is mismatch with organisational capability,(iii) lack of client's expertise,(iv) staffs' behaviour, (v) no support system (e.g., leader to guide) and comfortable with existing software. Based on these analyses, it is obviously reveal that high motivation has become an important capability factor to influence manager's decision in adopting BIM. This factor will be listed in the conceptual framework.

\section{B1: Motivation or support has positively influence manager's decision to adopt BIM software}

Second is commitment. It was found that if the top managers give full commitment towards changes (e.g., time, money and energy), the adoption of BIM software can be done quickly (e.g., Shiels, McIvor \& O'Reilly, 2003; Nguyen, Newby \& Macaulay, 2013). Some of the top managers (e.g.,A to M), have supported the works done by previous researchers. The manager from organisational B reveals his effort to survey appropriate software to expedite the qs works. Based on his high commitment to ensure qs profession are not left behind, he finally opts for Glodon software. Another group of managers (e.g., organisational C and D) refers to the group who intends to give full 
commitment provided that there is a leader to operate this system and sufficient 'fast- track' training. Despite they have already utilised BIM, they face difficulty to familiarise with this system. On top of that, they request support from staffs (e.g., organisational G and K) and sufficient trial period so that they can see clearly the changes involve within BIM software (e.g., organisational H). Meanwhile, there are some of the top managers (e.g., organisational A, E, F, H, J, L and M) which have not committed to adopt BIM within organisation due to several challenges. As a result, it can be concluded that high commitment is an important capability factor that could influence manager's decision in adopting. Thus, this factor will be listed in the conceptual framework.

\section{B2: Commitment has positively influence manager's decision to adopt BIM software}

Third is an attitude. The previous studies found that if top managers have no passion (Nor Hazana, Eta Wahab \& Alina, 2013) and afraid to take a risk (e.g., Spencer, Buhalis \& Moital, 2012), it will slow down the adoption of technology. This notion also has been supported by many other researchers (e.g., Ozorhon, Abbott \& Aouad, 2014; Zahrizan et al., 2013). The current findings (e.g., A,B,C,D,E,F,G,H,I,K and L) are consistent with previous literature, which acknowledged the positive correlation between managerial attitudes and decision to adopt BIM. First, is proactive attitude towards change shown by managers from organisational B. He was in the categories that love the changes. He will do the framework (planning to adopt extensively) and willingly to allocate fees to the software vendor just to ensure their organisation can learn, move and shows some progress. Second is the willingness to accept changes (replace the existing software with BIM software) among the case study organisations from the remaining organisations (e.g., C, D and K). From their point of view, it was not easy to complete the works (e.g., using new software) within a short period if it involves complex buildings. The emergence of Cost-X software also might expose them with the risks of accuracy. On top of that, the changes have become the main resistance among organisational B and C. This is because of the transition period in which involve insufficient learning time. This is supported by organisational $\mathrm{K}$ which admits the learning period involved in the transition process might be longer despite the readiness level towards BIM remains high. The cross case analyses is followed by third perspective shared by organisational A, E, G, H, L and M, which express their refusal towards change at the moment due to many reasons such as they are in a state of comfortable zone and facing the time constraints. They also do not have confident towards their clients as they have some problems handling technical works using BIM software. Meanwhile organisational $\mathrm{J}$ has not stated any ideas pertaining to the significance of their attitudes in influencing the adoption of BIM. Based on the majority views, this factor is relevant to be included in the conceptual framework.

\section{B3 : Attitudes has positively influence manager's decision to adopt BIM software}

Fourth is strategy. The importance of strategy in adopting BIM software has been described in earlier studies (e.g., Stewart \& Fenn, 2006, Pratali, 2003; Kearney, Harrington \& Kelliher, 2014). Using strategy, they could motivate organisation to adopt it quickly (e.g., Stewart \& Fenn, 2006) which includes developing new BIM unit, training, education program, changing management style and developing new roles and responsibilities. The top managers from current findings (e.g., B, C, D, I, K and L) is in agreement with abovementioned researchers which showed similarities in developing an appropriate strategy for innovation. Managers from organisational B, C, D,I and K extremely acknowledge the significance of strategies in expediting the adoption of BIM. These include the following matters: (i) collaborate with educational institution (e.g.,B), (ii) improve staffs recruitment and intranet working, upgrading the pc requirement and the selection of project which should match with their capability (e.g., C), (iii) purchasing one (1) license to familiarise with the system before intend to purchase other software (e.g., D) explore one (1) trial version to familiarise with the system (e.g., I, K) , establish a standard protocol and give training to the staffs below fifty (50) years old (e.g., I) and plans to have one Panel Consultant that could enforce the adoption of BIM (e.g., K). These views have been denied by managers from organisational G,L and M, which refuse to strategize any plans to adopt BIM sofware in future years. Despite they admit that BIM contain a lot of benefits in terms of having the potential to save their time to prepare a bq, they prefer to utilise existing software and search other alternatives to meet the deadline. For instance they prefer to do over time work to shorten the submission period and to complete within office hour. Meanwhile some of them (e.g.,A, E,F, H and J) do not share any views related to the significance of strategy in influencing the adoption of BIM. This factor will still be listed in the conceptual framework as there are some of the managers show the significance of this factor in influencing their decision to adopt BIM software.

\section{B4 : Strategy has positively influence manager's decision to adopt BIM software}

Fifth is leadership behaviour. Earlier studies have shown the significance of leadership behaviour in influencing managerial decision. The results of those studies indicate some leadership types in organisational innovation adoption such as transformational strategic leadership (e.g., Isabelle, Anita \& Fellows, 2014; Colbert, Barrick \& Bradley, 2014), strategic leadership (e.g., Carneiro, 2008); charismatic leadership (e.g., Isabelle, Anita \& Fellows, 2014) and champion (e.g., Egbu, 2004).The case study findings (e.g., A,B,C,G,I and K) are consistent with the ideas given by previous researchers. From the case study findings, the number of manager that shows their preference towards leadership behaviour is more than the number that those do not give any response. This is supported by the manager from organisational A which states their views about the significance to have leader in managing new software as they face some problems to manage junior staffs (either in technical part or administration part). Similar notions have been supported by organisational B and C, which stressed their need towards systematic support system. He added that managers from qs should not only be a leader but must have an IT based skills. Among the reasons that have been clearly stated are (i) to represent a good example (e.g., G), (ii) to fully manage the technical parts (e.g., M), (iii) to monitor the construction team (e.g., J) (iv) to reduce the learning time on BIM (e.g., I).Whereas the remaining top managers (e.g... D, E, F,H,J and L) have not stated any views related to the significance of leadership behaviour in influencing the adoption of BIM. Overall, the leadership behaviour is still relevant to be included in the conceptual framework based on the majority views shared by top manager. 


\subsubsection{Managerial Demographic Characteristics}

The analyses of non-behavioural capability factors are discussed into five (5) sub-themes which are age (DC1), experience (DC2), tenure (DC3), gender (DC4) and ethnicity (DC5).

First is age. The notion of the emerging case were consistent with those described by previous researchers (e.g., Awa et al., 2011; Chuang, Nakatani \& Zhou, 2009) related to the influence of age (seniority) in managerial adoption decision. For some managers (e.g., A, B, C,D, E, H, K and L) they feel confident to deal with BIM software despite they were old generation (above forty (40) years old). Similar notion have been shared by other group managers (e.g., A, B, C, D, E, H, K and L), which admit that their younger age have influenced them to adopt BIM software. In other situation, the adoption remains difficult despite their age are below forty (40) years old (e.g, M). Whereas for others, the resistance to adopt was high due to their increasing age (e.g, K, L). These analyses have considered age as an important factor to influence manager's decision in adopting BIM, since it has become the biggest resistance for some managers. Meanwhile, for others, age has not influenced them totally as long as they have passion towards new technology. Based on the majority of the managers agreed with the roles played by age (e.g., A,C,D,E,G,H,I,K and L) in influencing the adoption of BIM, this demographic characteristic will be listed in the conceptual framework.

\section{DC1: Age (seniority) has positively influence manager's decision to adopt BIM software}

Second is experience. The literature related to organisational innovation adoption reveal that experience of top managers always important in influencing managerial decision making (e.g., Carson \& Gilmore, 2000; Nur Mardhiyah, Hafez, Salleh \& Nur Khairul Faizah, 2012; Ozorhon; Abbott \& Aouad, 2014; Zahrizan et al., 2013). Majority of the case study findings (e.g., A,B,C,D,F,G,H,I,J,K,L and M) also consistent with the previous researchers. The managers from organisational A, C, E, J,L and M, stated that the exposure obtained from their working experience have definitely influenced their decision whether to accept or reject the adoption of BIM. All managers have agreed that based on their working exposure, some of them are quite reluctant to change, whereas some of them might have the intention to adopt it quickly. The case study organisations of B and D have shown their positive response towards BIM adoption after they managed to obtain some experiences working abroad (e.g UK and Australia) and utilise an advanced system. With such experience, they accept BIM with an open and positive mind. Based on their wide experience, managers from organisation B has shown positive response in detecting any design clashes via BIM. Similar to organisation C and D, the adoption of BIM is quite positive by starting to install two (2) licenses. The remaining managers from case study F, G, H, I, K also showed their positive response towards technological changes, but not into the stage of adopting BIM software. For instance, manager from organisational F and $\mathrm{G}$ which planning to set the target clearly before deciding to adopt BIM software or finding more experience. Following this situation, there are some manager that still searching the staffs to operate basic CAD system (e.g., H, I). It was believed that if the top managers exposed with an IT or advanced environment, the adoption of such software can be expedited (e.g., B,D and K).Thus, this demographic characteristics will be listed in the conceptual framework.

\section{DC2: Experience has positively influence manager's decision to adopt BIM software}

Third is tenure. The significance of tenure towards expediting BIM adoption is evidenced in the studies made by Colbert, Barrick \& Bradley, 2014). The study indicates the potential of younger managers with long tenure in the company are more favourable for teleworking than older managers with less tenure (e.g., Perez, Sanchez \& Carnicer, 2003).This notion was contradicts with construction industry when none of the top managers points out their opinion about the positive relationship between tenure and BIM adoption. This is consistent with the top managers from organisational B which have adopted BIM after his long tenure. Similarly happen by case study L, M, I, G and A, which refused to adopt BIM even they have worked for long tenure within their organisation. In another situation, the case study organisations $\mathrm{C}$ and D managed to adopt BIM despite their working experience within organisation is considered short. Meanwhile, the remaining case study organisations (e.g.,E,F,H,J and K) do not have any intention to adopt BIM for the time being. These findings suggest that working with long tenure could not determine the adoption of BIM can be expedited as it will goes back to the manager's personality. Thus, this demographic characteristic will not be listed in the conceptual framework.

\section{DC3 : Tenure has not influence manager's decision to adopt BIM software}

Fourth is gender. The significance of gender in influencing new software such as BIM was evidenced in the works of Barba-Sanchez, Martínez-Ruiz \& Jimenez-Zarco (2007), Awa et al. (2011), Colbert, Barrick \& Bradley (2014) and Chuang, Nakatani \& Zhou (2007). Surprisingly, no similar findings were found in the articles of Chuang, Nakatani \& Zhou (2009) and Chuang et al.,(2007). There are differences perspectives given by previous researchers. The case study findings followed the second perspectives in which found that gender is not important in influencing the decision making to adopt BIM. The managers from organisational A to M, admit that gender has not playing an important factor in BIM adoption. This is because there is no discussion has been made by them. Therefore, these findings suggest that gender has not given any effect towards managers in deciding whether to adopt BIM or not. Thus, this demographic characteristic will not listed in the conceptual framework.

DC4 : Gender has not influence manager's decision to adopt BIM software

Fifth is ethnicity. The top managers from emerging case have not discussed any relationship between ethnicity and BIM adoption. This result definitely does not support the previous research, which stressed ethnicity as an important factor (e.g., Barba-Sanchez, MartinezRuiz \& Jimenez-Zarco, 2007). The adoption of BIM have been successfully made (e.g., B to D) by Chinese and Malays managers. Meanwhile, the adoption of BIM remains difficult for some organisations (e.g., A,E, G and L). These findings suggest that types of ethnicity which possessed by managers does not affect their decision to adopt BIM software. Thus, this factor will not be listed in the conceptual framework. 
DC5: Ethnicity has not influence manager's decision to adopt BIM software

Sixth is academic qualification. From the previous studies, majority of the IT researchers have considered this factor as the main driver in influencing their decision to adopt new technology (e.g., Chuang, Nakatani \& Zhou, 2007; Chuang, Nakatani \& Zhou, 2009). The evidences were clearly supported by other researchers such as Spencer, Buhalis and Moital (2012), Mastura Jaafar et al. (2007), Chuang, Nakatani and Zhou (2007) and Henderson and Ruikar (2010). The previous results were consistent with the case study findings, which show the academic qualification as an indirect factor that might positively affect their mind setting. The top managers from organisational L, I and G admit the significant relationship between academic qualification and BIM adoption. This notion is supported by organisational $\mathrm{K}$. She claimed the attituditional behaviour of managers that (e.g.,openness towards changes) will ease the absorption of IT lesson. This is due to their wide exposure obtained during earlier stage of study. They have learned during studies and continue to use IT when working with one of the consultancy organisation located in abroad. The respondent from organisational I also personally accepts BIM software due to their wide exposure during pursuing master degree. Based on his IT background, the respondent managed to explore auto-CAD independently; this has become part of BIM software. This is consistent with organisational G, in which believed with the notion that academic qualification influencing the adoption of BIM. Meanwhile, another group of managers (e.g., A, B, C, D, E, F, H, J, K and M) denied the significance of this factor in influencing the BIM adoption. By considering the majority views that agree with this capability in contributing positive response towards BIM adoption, the demographic characteristics will be listed in the conceptual framework.

DC6: Academic qualification has positively influence manager's decision to adopt BIM software

The summary of the factors that might influence managerial decision making can be seen clearly in the following Table 3 .

Table 3 Managerial decision making capability to adopt BIM software in small and medium (SMEs) organisations

\begin{tabular}{|c|c|c|c|c|c|c|c|c|c|c|c|c|c|c|}
\hline \multicolumn{2}{|c|}{ Managerial Decision Making Capabilities } & \multicolumn{13}{|c|}{ Case Study Organisations } \\
\hline & & $\mathbf{A}$ & B & $\mathrm{C}$ & D & $\mathbf{E}$ & $\mathbf{F}$ & G & $\mathbf{H}$ & I & $\mathbf{J}$ & $\mathbf{K}$ & $\mathbf{L}$ & $\mathbf{M}$ \\
\hline \multicolumn{15}{|c|}{ Behavioural Capability } \\
\hline \multirow{4}{*}{ 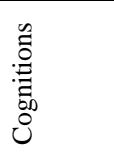 } & C1: Mindset Or Beliefs & $*$ & $*$ & $*$ & $*$ & $*$ & $*$ & $*$ & $*$ & $*$ & $*$ & $*$ & $*$ & $*$ \\
\hline & C2: Awarenesss & $*$ & $*$ & $*$ & $*$ & $*$ & $*$ & $*$ & $*$ & $*$ & $*$ & $*$ & $*$ & $*$ \\
\hline & C3: Vision & $*$ & $*$ & - & $*$ & $*$ & $*$ & $*$ & $*$ & $*$ & $*$ & $*$ & $*$ & $*$ \\
\hline & C4: Level Of Confident & $*$ & * & $*$ & $*$ & * & * & $*$ & * & $*$ & * & $*$ & * & * \\
\hline \multirow{2}{*}{$\overline{\tilde{D}} \approx \bar{U}$} & SC1 : External Relationship & $*$ & $*$ & - & $*$ & $*$ & $*$ & $*$ & $*$ & $*$ & $*$ & $*$ & $*$ & $*$ \\
\hline & SC2 : Internal Relationship & * & - & * & * & * & * & * & - & * & * & * & $*$ & * \\
\hline \multirow{8}{*}{ 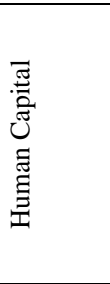 } & HC1 : Knowledge & $*$ & $*$ & $*$ & $*$ & $*$ & $*$ & $*$ & $*$ & $*$ & $*$ & $*$ & $*$ & $*$ \\
\hline & HC2 :Training & $*$ & $*$ & $*$ & $*$ & $*$ & $*$ & $*$ & $*$ & $*$ & $*$ & $*$ & $*$ & - \\
\hline & HC3 : It Skill & - & $*$ & - & $*$ & $*$ & $*$ & $*$ & $*$ & $*$ & $*$ & $*$ & - & $*$ \\
\hline & HC4 : Personnel Skill & $*$ & $*$ & - & - & - & $*$ & $*$ & - & - & - & - & $*$ & - \\
\hline & HC5 : Managerial Skill & $*$ & $*$ & - & - & - & - & $*$ & - & - & - & $*$ & - & - \\
\hline & HC6 : Problem Solving Skill & $*$ & - & - & - & - & - & $*$ & - & - & - & - & - & - \\
\hline & HC7 : Entrepreneurial Skill & - & - & - & - & - & - & $*$ & - & - & - & - & - & - \\
\hline & HC8: Technical Skill & * & $*$ & $*$ & $*$ & $*$ & * & $*$ & - & $*$ & * & - & * & $*$ \\
\hline \multirow{5}{*}{ 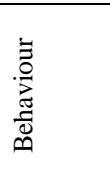 } & B1: Motivation Or Support & * & $*$ & $*$ & $*$ & $*$ & $*$ & $*$ & * & $*$ & * & $*$ & * & $*$ \\
\hline & B2: Commitment & $*$ & $*$ & $*$ & $*$ & $*$ & $*$ & $*$ & $*$ & $*$ & $*$ & $*$ & * & $*$ \\
\hline & B3: Attitudes & $*$ & $*$ & $*$ & $*$ & $*$ & $*$ & $*$ & $*$ & $*$ & - & $*$ & $*$ & $*$ \\
\hline & B4: Strategy & - & $*$ & $*$ & $*$ & - & - & $*$ & - & $*$ & - & $*$ & $*$ & $*$ \\
\hline & B5: Leadership Behaviour & $*$ & * & * & - & - & - & $*$ & - & $*$ & - & $*$ & - & $*$ \\
\hline \multicolumn{15}{|c|}{ Non- Behavioural Capability } \\
\hline \multirow{6}{*}{ 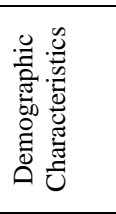 } & DC1: Age & $*$ & $*$ & $*$ & $*$ & $*$ & $*$ & $*$ & $*$ & $*$ & - & $*$ & $*$ & $*$ \\
\hline & DC2: Experience & $*$ & $*$ & $*$ & $*$ & $*$ & $*$ & $*$ & $*$ & $*$ & $*$ & $*$ & $*$ & $*$ \\
\hline & DC3: Tenure & - & - & - & - & - & - & - & - & - & - & - & - & - \\
\hline & DC4: Gender & - & - & - & - & - & - & - & - & - & - & - & - & - \\
\hline & DC5: Ethnicity & - & - & - & - & - & - & - & - & - & - & - & - & - \\
\hline & DC6: DC6: Academic Qualification & - & - & - & - & - & - & * & - & * & - & - & * & - \\
\hline
\end{tabular}

* there is view given by top manager

- there is no view given by top manager

Based on the the comparative analysis (cross-case) made between existing theories and new concepts raised by top managers, there are some similarities and differences involves in terms of views given by top managers. It was found that both case studies findings and previous literatures indicate similarities in giving their point of views, by classifying the managerial capability or known as managerial decision making capability into two (2) broad capability, which are non-behavioral and behavioral capability factors. As for behavioural capability, the case study organisations indicate similarity of the factors as listed in the initial conceptual framework. Based on the majority of the views obtained from top managers, there are four (4) main factors (themes) have been considered important namely: (i) cognitions (C1 : Mindset or beliefs , C2 : Awareness , C3 : Vision , C4 : Level of confident) (ii) social capital (SC1 :External relationship , SC2 : 
Internal relationship) (iii) human capital (HC1 : Knowledge , HC2 : Training, HC3 : IT skill , HC4 : Personnel skill , HC5 : Managerial skill , HC8 : Technical skill) and (iv) behavior ( B1: Motivation or support, B2: Commitment , B3 : Attitudes , B4 : Strategy , B5: Leadership behaviour). These include the non-behavioural capability, which viewed DC1: Age, DC2: Experience and DC6: Academic qualification as an important factor.

However, the top managers also shared differences in giving their views pertaining to certain capability factors listed in the conceptual framework. They denied some behavioural capability factors which has been highlighted in the earlier studies namely HC6: Problem solving skill and HC7: Entrepreneurial skill; and non-behavioural capability namely DC3: Tenure, DC4: Gender and DC5: Ethnicity. Within construction SMEs, these factors were not important after receiving the negative response from respondents (see explanation in section 5.3). Some of them claimed that those factors do not play an important factor in influencing managerial decision, while another group of managers do not give any point of views). They also believed that those factors were not suitable for construction industry. Therefore, it will not be included in the final conceptual framework.

From these findings also, it can be concluded that SMEs managers do not possesses sufficient capability (both capability factors). For instance, they might have been equipped with good mindset or beliefs, awareness, vision, but still fails to adopt BIM in future years, because they do not have sufficient knowledge regarding BIM software. They also faced various challenges in expediting the decision to adopt BIM software such as due to the technological issues (see further details in results and discussion). This is the main reason of why top managers from QS fields were quite reluctant in accepting new changes, in which cause the adoption of new technology (e.g., BIM) remains slow. In fact, they were quite left behind compared to other organisation namely architects. This research provides meaningful contribution in the body of knowledge of construction innovation especially within Malaysian SMEs and qs fields especially.

\subsection{Revised Conceptual Framework on the Managerial Decision Making Capability in Adopting BIM software}

It can be summarized from Figure 2 that generally both the case studies' findings and previous literatures indicate similarities in giving their point of views, by classifying the managerial capability or known as managerial decision making capability into two (2) broad capability, which are (1) non-behavioral, and (2) behavioral capability factors.

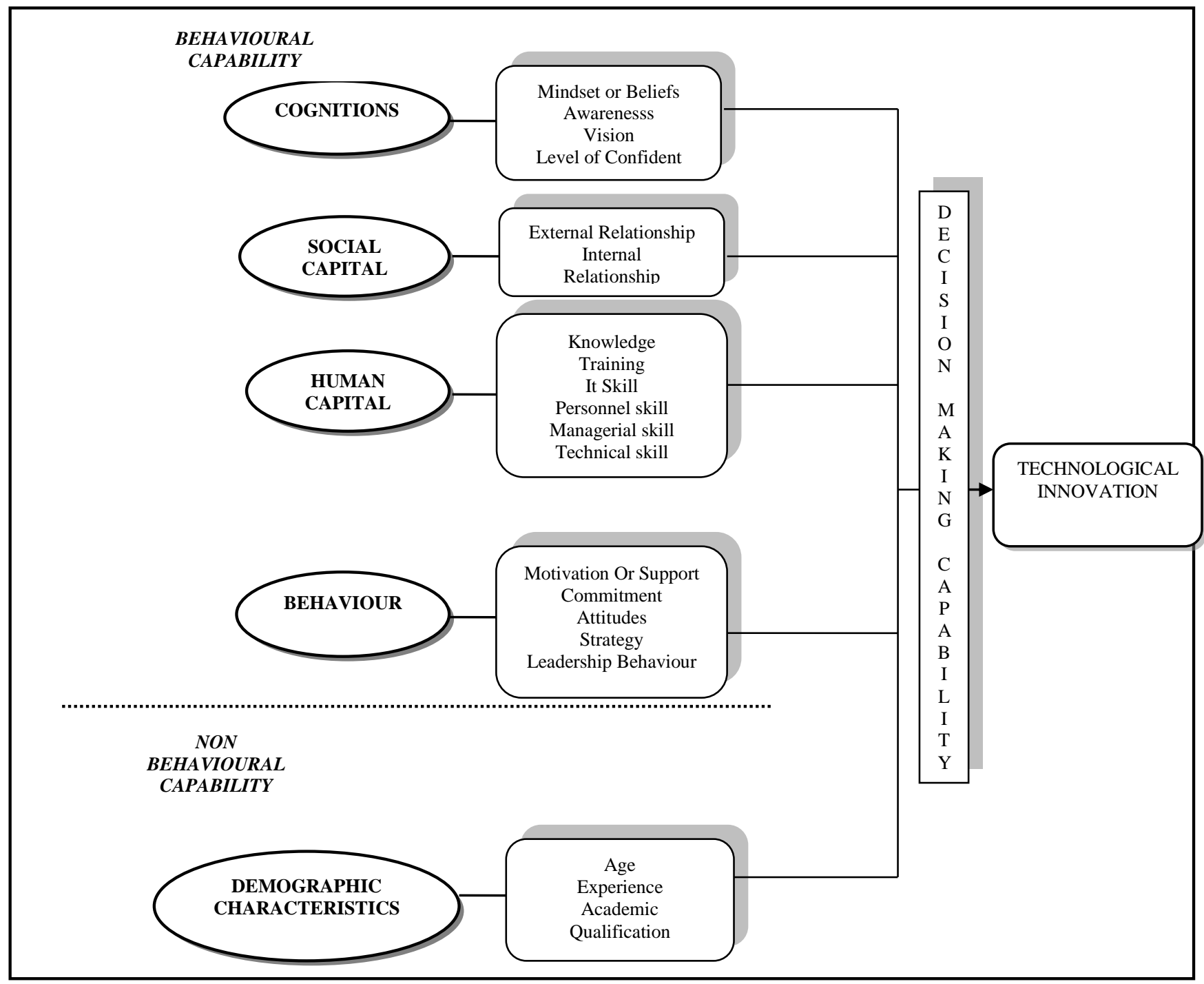

Figure 2 A final conceptual frameworks related to managerial decision making capability 
This framework provides a new insight for construction SMEs especially within qs context due to the framework has been proposed based on the qualitative approach. Moreover, the qualitative studies have been conducted as there were no studies being made based on managerial perspective. Therefore, via this study, the factors influencing the adoption of new technology have been extended to managerial capability. This is consistent with the limited empirical research involving top managers (e.g., Oppong, 2014). The previous study also tends to emphasize more on the adoption of new technology among other industries. In fact, the study has not sufficiently focused the adoption of specific technology namely BIM software. It is hoped that the influential factors related to top managers (e.g, capability) in which caused the slow adoption of new technology (e.g.,BIM software) can be a comprehensive framework for construction SMEs. The final conceptual framework remains an important guideline for them as they can understand the area of capability that requires improvement (determine the level of adoption capability). In doing so, they can improve their adoption decision capability by planning an appropriate strategy.

\subsection{CONCLUSION}

The main objective of this research is to achieve the aim of the research, which is to develop a conceptual framework related to managerial decision making capability (see Figure 2). It can be clearly seen that from five (5) main themes, both findings have denied some of the factors namely ethnicity, gender, tenure, problem solving skill and entrepreneurial skill. The abovementioned capabilities were not important in influencing the managerial adoption decision in order to adopt technology innovation (e.g., BIM software). This study also suggests that the adoption of new technology (e.g., BIM software) among construction SMEs has been largely influenced by the top managers' decision making capability. This means that the adoption of new technology could be expedite if they possess and maximize all capabilities as shown in Figure 2. The decision making framework can be further extended to other construction organisations (do not limit to qs only). Therefore, similar research should be undertaken by contractors' organisation in which interested and have grapple with new technology (e.g., BIM software). The next study is to validate the conceptual framework before finalising the findings.

\section{References}

Abdullah, M. R., Abdul Azis, A. A., \& Abdul Rahman, I. (2009). Causes Of Delay And Its Effects In Large MARA Construction Project. International Journal Of Integrated Engineering (Issue on Mechanical, Materials and Manufacturing Engineering).

Afzaal H. Seyal., Mohd Noah Abd Rahman., \& Hj Awg Yussof Hj Awg Mohammad. (2007). A Quantitative Analysis Of Factors Contributing Electronic Data Interchange Adoption Among Bruneian Smes: A Pilot Study. Business Process Management Journal, 13 (5), 728-746. Retrieved August 11, from, http://www,emeraldinsight.com.

Aslan, Sebnem and Diken, Ahmet \& Sendogdu, A. Aslan, (2011). Investigation Of The Effects Of Strategic Leadership On Strategic Change And Innovativeness Of Smes In A Perceived Environmental Uncertainity. Procedia Social And Behavioral Sciences, 24, 627-642.

Awa, H. O., Eze, S. C., Urieto, J. E., \& Inyang, B. J. (2011). Upper Echelon Theory (UET) A Major Determinant Of Information Technology (IT) Adoption By SMEs In Nigeria. Journal Of Systems And Information Technology, 13(2), 144-162.

Azadegan, A., \& Teich, J. (2010). Effective Benchmarking Of Innovation Adoptions: A Theoretical Framework For E-Procurement Technologies. Benchmarking: An International Journal, 17(4), 472 - 490. Retrieved August 11, from, http://www.emeraldinsight.com

Babbie, E. R. (2010). The Practice Of Social Research, (12th Ed.), Belmont, CA: Thomson Wadsworth

Barba-sanchez, V., Martínez-ruiz, M. P., \& Jiménez-zarco, A. I. (2007). Drivers, Benefits And Challenges Of ICT Adoption By Small And Medium Sized Enterprises (Smes): A Literature Review. Problems And Perspectives In Management, 5(1), 103-114

Barlish, K. \& Sullivan, K. (2012). How To Measure The Benefits Of BIM - A Case Study Approach. Automation in Construction, 24, 149-159.

Barney, J. B. (2001). Resource-Based Theories Of Competitive Advantage: A Ten-Year Retrospective On The Resource-Based View. Journal Of Management,27(6), 643-650.

Beerel, A. (2009). Leadership and change management. Sage.

Bhattacherjee, A. (2012). Social Science Research: Principles, Methods, And Practices. Textbooks Collection. Retrieved August 11, from, http:// scholarcommons.usf.edu/oa_textbooks

Breuer, J., \& Fischer, M. (1994). Managerial Aspects Of Information-Technology Strategies For A/E/C Firms. Journal Of Management In Engineering, 10(4), 52-59.

Brewer, G., \& Runeson, G. (2009). Innovation And Attitude: Mapping The Profile Of ICT Decision-Makers In Architectural, Engineering And Construction Firms. International Journal Of Managing Projects In Business, 2(4), 599- 610. Retrieved August 11, from, http://www,emeraldinsight.com

Carneiro, A. (2008). When Leadership Means More Innovation And Development. Business Strategy Series, 9(4), 176 - 184. Retrieved August 11, from, http://www.emeraldinsight.com.

Carson, D. \& Gilmore, A. (2000). SME Marketing Management Competencies. International Business Review, 9, 363-382. Retrieved August 11, from, http://www.sciencedirect.com

Chuang, T. T., Nakatani, K., \& Zhou, D. (2009). An Exploratory Study Of The Extent Of Information Technology Adoption In SMEs: An Application Of Upper Echelon Theory. Journal Of Enterprise Information Management, 22(1/2), 183-196.

Chuang, T. T., Nakatani, K., Chen, J. C., \& Huang, I. L. (2007). Examining The Impact Of Organisational And Owner's Characteristics On The Extent Of ECommerce Adoption In SMEs. International Journal Of Business And Systems Research, 1(1), 61-80. Retrieved August 11, from, http:// inderscienceonline.com

Chuang, T.T., Nakatani, K., \& Zhou, D. (2007). The Impact Of Managerial Characteristics Of Top Management Team On The Extent Of Information Technology Adoption: An Exploratory Study With The Upper Echelon Theory. AMCIS 2007 Proceedings. Paper 149. Retrieved August 11, from, http://www.aisel.aisnet.org/amcis2007/149

Colbert, A.E., Barrick, M.R., \& Bradley, B.H. (2014). Personality And Leadership Composition In Top Management Teams: Implications For Organizational Effectiveness, Personnel Psychology, 67, (2), 351-387.

Construction Research Institute of Malaysia (CREAM). Issues And Challenges In Implementing BIM For Building Information Modelling SME's In The Construction Industry. Paper Presented at the Seminar and Workshop on Issues and Challenges in Implementing Building Information Modelling (BIM) By Small And Medium Enterprises (SME's) In The Construction Industry. Retrieved September 11, 2015 from, https://www.cidb.gov.my

Creswell, J. W. (2008). Research Design: Qualitative, Quantitative, And Mixed Methods Approaches, 816- 817. Thousand Oaks, CA: SAGE Publications, Inc.

Easterby-Smith M, Thorpe R., \& Lowe, A. (2002). 2nd Ed. Management Research - An Introduction. Sage: London.

Eckenhofer, E. M. (2011, January). Network Management As A Way To Manage Intellectual Capital. In Proceedings Of The 12th European Conference On Knowledge Management-ECKM 2011.

Egbu, C.O. (2004). Managing Knowledge And Intellectual Capital For Improved Organisational Innovations In The Construction Industry: An Examination Of Critical Success Factors. Engineering, Construction And Architectural Management (ECAM). 11 (5), 301 - 315. 
Faizul, A.Rahim., Nurshuhada, Zainon. \& Hafez, Salleh. (2012). The Information Technology Application Change Trend: Its Implications For The Construction Industry. Journal Of Surveying, Construction And Property, 2, 6-20.

Fellows, R., \& Liu, A. (2008). Research Methods For Construction, (3rd Ed). Chichester :WileyBlackwell.

Fink, D. (1998). Guidelines For The Successful Adoption Of IT In SMEs. International Journal of Information Management, 18(4), 243-53. Retrieved August 11, from, http://www. sciencedirect.com

Fitjar, R. D., Gjelsvik, M., \& Rodríguez-Pose, A. (2013). The Combined Impact Of Managerial And Relational Capabilities On Innovation In Firms. Entrepreneurship \& Regional Development, 25(5-6), 500-520

Garaca, Z . (2011). Factors Related To The Intended Use Of ERP Systems, Management, 16(2), 23-42.

Garcia-Morales, V. J., Jimenez-Barrionuevo, M. M., \& Gutierrez-Gutierrez, L. (2012). Transformational Leadership Influence On Organizational Performance Through Organizational Learning And Innovation. Journal Of Business Research, 65(7), 1040-1050. Retrieved August 11, from http: //www. elsevier.com

Gayathri Nagalingam, Himal Jayasena \& K.A.T.O. Ranadewa (2013), Building Information Modelling And Future Of Quantity Surveyors Practice In Sri Lankan Construction Industry, available online from http://www.irbnet.de/daten/iconda/CIB_DC26703.pdf

Geletkanycz, M. A., \& Hambrick, D. C. (1997). The External Ties Of Top Executives: Implications For Strategic Choice And Performance. Administrative Science Quarterly, 42(4),654-681.

Ghobakhloo, M., Tang S, H., Mohammad Sadegh Sabouri., \& Norzima Zulkifli. (2012). Strategies For Successful Information Technology Adoption In Small And Medium-Sized Enterprises, Information, 3 (1), 36-67. Retrieved August 11, from, http://www.mdpi.com

Hai G., Jing Z. \& Jintong T., (2013). The Role Of Top Managers' Human And Social Capital In Business Model Innovation. Chinese Management Studies, 7(3), 447 469. Retrieved August 11, from, http://www.emeraldinsight.com.

Hassan Issa, Abdul Kareem., \& Abu Hassan., Abu Bakar. (2011). Identifying It Benefits For Malaysian Construction Companies. Journal of Information Technology in Construction (Itcon), 16, 477-492.

Helfat, C. E., \& Peteraf, M. A. (2015). Managerial Cognitive Capabilities And The Microfoundations Of Dynamic Capabilities. Strategic Management Journal, 36(6), $831-850$.

Henderson, J. R., \& Ruikar, K. (2010). Technology Implementation Strategies For Construction Organisations. Engineering, Construction And Architectural Management, 17(3), 309-327.

Hua,Y. Y., \& Chan, I. Y. S. (2013). Development Of A Conceptual Model For Organizational Learning Culture And Innovation Diffusion In Construction. In: Smith, S D (Ed.) and Ahiaga-Dagbui, D D (Ed.), Proceedings 29th Annual ARCOM Conference, 2-4 September 2013, Reading, UK, Association of Researchers in Construction Management., 405-414.

Hunter, S. T. \& Cushenbery, L. (2011), Leading For Innovation: Direct And Indirect Influences. Advances in Developing Human Resources, 13(3), 248-265.

Isabelle, Y., S. Chan, Anita M., M., Liu., \& Fellows, R. (2014). Role Of Leadership In Fostering An Innovation Climate In Construction Firms. J. Manage. Eng., 30(6), 06014003.

Jackson, S., Farndale, E., \& Kakabadse, A. (2003). Executive Development: Meeting The Needs Of Top Teams And Boards. Journal of Management Development, $22(3), 185-265$

Jong, J. De., \& Hartog, D. Den (2003). Research Report H200303. Leadership As A Determinant Of Innovative Behaviour A Conceptual Framework. Netherlands: Scientific Analysis Of Entrepreneurship And SMEs (SCALE)

Junaidah Hashim. (2007). Information Communication Technology (ICT) Adoption Among SME Owners in Malaysia. International Journal of Business and Information, 2 (2), 221 - 240. Retrieved August 11, from, http://www.knowledgetaiwan.org

Kaming, P. F., Olomolaiye, P. O., Corbett, P., \& Harris, F. C. (1994). A Framework For The Strategic Development Of The Construction Industry In Developing Countries: Six Strategic Approaches To Construction Industry Development In Developing Countries Identified. Building Research And Information, 22(6), 325-331.

Kearney, A., Harrington, D. \& Kelliher, F. (2014). Exploiting Managerial Capability For Innovation In A Micro-Firm Context: New And Emerging Perspectives Within The Irish Hotel Industry, European Journal Of Training And Development, 38(1), 95-117.

Khong, S. T., Siong C. C., Binshan L., \& Uchenna C. E., (2010). Internet-Based ICT Adoption Among SMEs: Demographic Versus Benefits, Barriers, And Adoption Intention. Journal Of Enterprise Information Management, 23(1), 27 - 55. Retrieved August 11, from, http://www.emeraldinsight.com

Kor, Y. Y., \& Mesko, A. (2013). Dynamic Managerial Capabilities: Configuration And Orchestration Of Top Executives' Capabilities And The Firm's Dominant Logic. Strategic Management Journal, 34(2), 233-244.

Lester, S. (2014). Professional Standards, Competence And Capability. Higher Education, Skills And Work-Based Learning, 4(1), 31-43.

Luoma, M. (2000). Developing People For Business Success: Capability-Driven HRD In Practice, Management Decision, 38 (3), 145-153.

Manral, L. (2011). Managerial Cognition As Bases Of Innovation In Organization. Management Research Review, 34(5), 576 - 594 Retrieved August 11, from, http://www,emeraldinsight.com

Mastura Jaafar., T. Ramayah., Abdul-Rashid Abdul-Aziz., \& Basri Saad. (2007).Technology Readiness Among Managers Of Malaysian Construction Firms. Engineering, Construction And Architectural Management, 14(2), 180-19. Retrieved August 9, from, http://www.emeraldinsight.com

Mazuki Jusoh, Mohd. Rizal Abdul Razak., \& Maimun Simun. (2004). Integration Of Information Technology Among Small And Medium-Sized Enterprises In Malaysia: A Value-Chain Examination. Journal Of Small Business \& Entrepreneurship,17(3), 187-204.

Meng-Han T., Mom, M., \& Shang-Hsien., H. (2014). Developing Critical Success Factors For The Assessment Of BIM Technology Adoption: Part I. Methodology And Survey. Journal Of The Chinese Institute Of Engineers, 37(7), 845-858. Retrieved August 11, from, http://www.tandfonline.com.

Meriam, S.B. (2001). Qualitative Research And Case Study Applications In Education. San Francisco: Jossey-Bass.

Miles, M.B., \& Huberman, A.M. (1994). Qualitative Data Analysis: An Expanded Sourcebook. London: Sage Publications.

Mitropoulos, P., \& Tatum, C.B. (1999). Technology Adoption Decisions In Construction Organizations. Journal Of Construction Engineering And Management, 125 (5), 330-338 Retrieved August 11, from, http:www.ascelibrary.org/

Mohd Nawi, Mohd Nasrun Lee, Angela, Noor, Mohamed, Azman, Azhari, Mohamad Kamar. \& Kamarul Anuar.(2014). Fragmentation Issue In Malaysian Industrialised Building System (IBS) Projects. Journal Of Engineering Science And Technology, 9 (1), 97-106. Retrieved August 9, from, http://www. jestec.taylors.edu.my

Mohr ,J., Sengupta, S., \& Slater, S. (2009). Marketing of High-Technology Products and Innovations, 3rd Edn. Upper Saddle River, NJ: Prentice Hall.

Morgan, D.L. (2008). The SAGE Encyclopedia of Qualitative Research Methods. Thousand Oaks, CA: SAGE Publications, Inc.

Mumtaz Abdul Hameed., \& Counsell, S and Swift, S (2012). A Conceptual Model For The Process Of IT Innovation Adoption In Organizations. Journal Of Engineering And Technology Management, 29(3), 358-390.

Nam, C. H., \& Tatum, C. B. (1997). Leaders And Champions For Construction Innovation. Construction Management \& Economics, 15(3), 259-270.

Nguyen, T.H., Newby, M., \& Macaulay, M.J. (2013). Information Technology Adoption In Small Business: Confirmation Of A Proposed Framework. Journal Of Small Business Management, 53(1), 207-227, Retrieved August 11, from, http://www.ssrn.com

Nooraie, M. (2012). Factors Influencing Strategic Decision-Making Processes. International Journal Of Academic Research In Business And Social Sciences, 2(7), 405-429.

Nor Hazana, Abdullah., Eta Wahab., \& Alina Shamsuddin. (2013). Exploring The Common Technology Adoption Enablers Among Malaysian Smes: Qualitative Findings. Journal Of Management And Sustainability, 3(4), 78-91. Retrieved August 11, from, http://www. .ccsenet.org

Nur Mardhiyah, Aziz, Hafez, Salleh. \& Nur Khairul Faizah Mustafa. (2012). People Critical Success Factors (Csfs) In Information Technology/Information System (IT/IS) Implementation, Journal Design And Built, 5(1), 1-17.

Nuradillin Hasnul Hafidzan. (2015) A Study On The Level Of Usage Of Ict Specialized Software In Preparation Bill Of Quantities In Small-Medium Quantity Surveying Firms. Unpublished dissertation, Deakin University, Australia

Oliveira, T., \& Martins, M. F. (2010). Literature Review Of Information Technology Adoption Models At Firm Level, The Electronic Journal Information Systems Evaluation, 14(1), 110-121. 
Ongori, H., \& Migiro, S.O. (2010). Information And Communication Technologies Adoption In Smes: Literature Review. Journal Of Chinese Entrepreneurship, 2(1), 93 - 104. Retrieved August 11, from, http://www.emeraldinsight.com

Oppong, S. (2014). Upper Echelons Theory Revisited: The Need For A Change From Causal Description To Casual Explanation. Management: Journal Of Contemporary Management Issues, 19(2), 169-183

Ozorhon, B. (2013). Analysis Of Construction Innovation Process At Project Level. ASCE Journal Of Management In Engineering, 29(4), 455-463. Retrieved August 11, from, http://www. ascelibrary.org

Ozorhon, B., Abbott, C., \& Aouad, G. (2014). Integration And Leadership As Enablers Of Innovation In Construction: Case Study. Journal Of Management In Engineering, American Society Of Civil Engineers, 30 (2), 256-263. Retrieved August 11, from, http://www. ascelibrary.org

Peansupap, V., \& Walker, D. (2005a). Exploratory Factors Influencing Information And Communication Technology Diffusion And Adoption Within Australian Construction Organizations: A Micro Analysis. Construction Innovation: Information, Process, Management, 5(3),135-157.

Peansupap, V., \& Walker, D. H. (2006). Information Communication Technology (ICT) Implementation Constraints: A Construction Industry Perspective. Engineering, Construction And Architectural Management, 13(4), 364-379.

Peltier, J. W., Zhao, Y., \& Schibrowsky, J. A. (2012). Technology Adoption By Small Businesses: An Exploratory Study Of The Interrelationships Of Owner And Environmental Factors. International Small Business Journal, 30(4), 406-431.

Perez, M.P, Sanchez, A.M., \& Carnicer, M.P.D.L. (2003). Top Manager And Institutional Effects On The Adoption Of Innovations: The Case Of Teleworking 1, 21(1), 58-73. Retrieved August 11, from, http:// www.tandfonline.com

Pratali, P. (2003). Strategic Management Of Technological Innovations In The Small To Medium Enterprise. European Journal Of Innovation Management, 6(1), 18 31. Retrieved August 11, from, http://www,emeraldinsight.com

Razak Bin Ibrahim, A., Roy, M. H., Ahmed, Z., \& Imtiaz, G. (2010). An Investigation Of The Status Of The Malaysian Construction Industry. Benchmarking: An International Journal, 17(2), 294-308. Retrieved August 11, from, http://www.emeraldinsight.com

Ren, A., \& Kumaraswamy, M.M. (2013). Exploring The Conflicts Between BIM And Existing Project Processes In Hong Kong, In Building And Construction (CIB) World Building Congress 2013 Proceedings Of The International Council For Research And Innovation in, 5th -9th May, Brisbane, Australia.

Rezgui, Y., Beach, T., \& Rana, O. (2013). A Governance Approach For Bim Management Across Lifecycle And Supply Chains Using Mixed-Modes Of Information Delivery. Journal Of Civil Engineering And Management, 19(2), 239-258.

Russell, D. M., \& Hoag, A. M. (2004). People And Information Technology In The Supply Chain: Social And Organizational Influences On Adoption. International Journal Of Physical Distribution And Logistics Management, 34 (2), 102-122.

Sackey, E., Tuuli, M., \& Dainty., A. (2013, June 20). Sociotechnical Alignment And Innovation In Construction; The Case Of BIM Implementation In A Heterogeneous Context. Paper Presented At The ARCOM Doctoral Workshop On BIM Management And Interoperability, Birmingham City University, UK, London : Association Of Researchers In Construction Management.

Sexton, M, Barrett, P., \& Ghassan Aouad. (2006). Motivating Small Construction Companies To Adopt New Technology. Building Research And Information, 34(1), 11-22. Retrieved August 11, from, http://www.tandfonline.com

Seyal, A. H., Mohd Noah Abd Rahman., \& Awg Yussof Hj Awg Mohammad, H. (2007). A Quantitative Analysis Of Factors Contributing Electronic Data Interchange Adoption Among Bruneian Smes: A Pilot Study. Business Process Management Journal, 13(5), 728-746.

Shiels,H., McIvor, R., \& O'Reilly, D. (2003). Understanding The Implications Of ICT Adoption: Insights From Smes. Logistics Information Management, 16(5), 312 - 326. Retrieved August 11, from, http://www,emeraldinsight.com

Simmons, G., Armstrong, G.A., \& Durkin, M.G. (2008). A Conceptualization Of The Determinants Of Small Business Website Adoption. Setting The Research Agenda . International Small Business Journal, 26 (3), 351-389. Retrieved August 11, from, http://www isb.sagepub.com

Spencer, A. J., Buhalis, D., \& Moital.M. (2012). A Hierarchical Model Of Technology Adoption For Small Owner-Managed Travel Firms: An Organizational Decision-Making And Leadership Perspective. Tourism Management, 33(5). 1195-1208. Retrieved August 11, from, http://www,emeraldinsight.com

Stewart, I.,\& Fenn, P. (2006). Strategy: The Motivation For Innovation. Construction Innovation, 6(3), 173 - 185. Retrieved August 11, from, http://www.emeraldinsight.com

Tamkin, P., Hillage, J., \& Willison, R. (2002). Indicators Of Management Capability: Developing A Framework. London, Council For Excellence In Management And Leadership.

Tan \& Ter, C. F. (2010). A Perception-Based Model For Technological Innovation In Small And Medium Enterprises. Journal 18th European Conference On Information Systems, 1-13.

Ta-Tao Chuang, Kazuo Nakatani., \& Duanning Zhou. (2009). An Exploratory Study Of The Extent Of Information Technology Adoption In Smes: An Application Of Upper Echelon Theory, Journal Of Enterprise Information Management, 22(1/2), 183 - 196.

Ta-Tao, C., Zhou, D., \& Nakatani, K (2007). The Impact Of Managerial Characteristics Of Top Management Team On The Extent Of Information Technology Adoption: An Exploratory Study With The Upper Echelon Theory.AMCIS 2007 Proceedings, 149.

Tatum, C.B. (1987). Process Of Innovation In Construction Firm. Journal Constr. Engrg. And Mgmt, ASCE, 113 (4), 648- 663.

Thurairajah, N., \& Goucher, D. (2013, November). Advantages And Challenges Of Using BIM: A Cost Consultant's Perspective. In 49th ASC Annual International Conference Proceedings (pp. 1-8).

Vincent, L. (2008). Differentiating Competence, Capability And Capacity. Innovating Perspectives, 16(3), 1-2.

Whyte, J., Bouchlaghem, D., \& Thorpe, T. (2002). IT Implementation In The Construction Organization. Engineering Construction And Architectural Management, 9(5-6), 371-377. Retrieved August 11, from http: //www.wiley online library

Wong, K. \& Fan, Q., (2013). Building Information Modelling (BIM) For Sustainable Building Design. Facilities, 31(3/4), 138-157.

Wu, W.-W. (2011). Developing An Explorative Model For Saas Adoption, Expert Systems With Applications, 38(12), 15057-15064

Yang Jay, Ahuja Vanita., \& Shankar Ravi. (2007). Managing Building Projects Through Enhanced Communication - An ICT Based Strategy For Small And Medium Enterprises, CIB World Building Congress 2007, 2334-2356. CIB: South Africa

Yin, R. K. (2009). Case Study Research: Design And Methods, 4th. Thousand Oaks.

Zahrizan, Nasly Mohamed Ali., Ahmad Tarmizi Haron., Marshall-Ponting., \& Zuhairi Abd Hamid. (2013). Exploring The Adoption Of Building Information Modelling (BIM ) In The Malaysian Construction Industry : A Qualitative Approach. International Journal Of Research In Engineering And Technology (IJRET), 2(8), 384-395.

Zainon, N., Salleh, H., \& Rahim, F. A. (2011). Coping With The Rapidity Of Information Technology Changes -- A Comparison Review On Current Practices. World Academy Of Science, Engineering \& Technology, 80427-433.

Zhang, B., \& Tao, Q., (2012). Research Of SMEs' Technology Innovation Model From Multiple Perspectives. Chinese Management Studies, 6(1), 124 - 136. Retrieved August 11, from, http: //www.emeraldinsight.com

Zhou, Lei., Perera, Srinath, Udeaja, Chika., \& Paul, Charlotte. (2012, September 5-9). Readiness Of BIM: A Case Study Of A Quantity Surveying Organisation. Paper presented at the First UK Academic Conference on BIM, Northumbria University, Newcastle- upon-Tyne, UK. 